\title{
Milk protein-iron complexes: Inhibition of lipid oxidation in an emulsion
}

\author{
Maya Sugiarto, Aiqian Ye, Michael W. TaYlor, Harjinder Singh* \\ Riddet Institute, Massey University, Private Bag 11 222, Palmerston North, New Zealand
}

Received 5 July 2009 - Revised 15 October 2009 - Accepted 10 November 2009

Published online 17 December 2009

\begin{abstract}
Fortification of foods with iron is a common vehicle for delivering iron in required quantities to the consumer. However, many technological problems occur when food products are fortified with minerals, due mainly to the many reactions of minerals with other food components, e.g. fat oxidation. In the present study, the binding of iron (ferrous sulphate) to common milk protein products, sodium caseinate, whey protein isolate (WPI) and milk protein concentrate (MPC), to form protein-iron complexes was characterized by the amount of iron binding and the turbidity as functions of the iron concentration. In an emulsion containing linoleic acid, the oxidation activity of these protein-iron complexes was compared with that of the iron in its free state. The affinities of caseinate and MPC to bind iron were higher than that of WPI. These differences were attributed to the presence of clusters of phosphoserine residues in casein molecules, that are known to bind divalent cations strongly. Lipid oxidation experiments showed that the ability of iron to catalyse lipid oxidation was reduced significantly when iron was bound to protein compared with when it was in its free form. This suggests that the formation of milk protein-iron complexes could be a novel way of incorporating iron into food products with high bioavailability, good flavour and no solubility problems.
\end{abstract}

sodium caseinate / whey protein isolate / milk protein concentrate / protein-iron complex / emulsion oxidation

\begin{abstract}
摘要 - 乳状液体系中乳蛋白一铁复合物对脂肪氧化的抑制作用。在食品中强化铁元素是 补充人体所需要铁的一种重要手段。由于矿物元素与食品中成分发生反应, 如氧化反应 等, 给强化了矿物元素的食品带来很多技术上的问题。本文研究了不同浓度的硫酸亚铁 与普通的乳蛋白、酪蛋白酸钠、乳清分离蛋白、乳清浓缩蛋白形成的铁-乳蛋白复合物与 浊度之间的关系。在含有亚油酸的乳浊液中, 比较了这些铁复合物和游离铁的氧化活性。 酪蛋白酸钠和乳清浓缩蛋白对铁的结合能力高于乳清分离蛋白。这种差异是由于酪蛋白 分子中的磷酸化丝氨酸残基的簇状结构对二价阳离子具有较强的结合能力。脂肪氧化试 验表明结合态铁的氧化能力显著地低于游离态的铁。这就意味着这种铁-蛋白复合物可能成 为食品工业中新型的铁强化剂。
\end{abstract}

\section{酪蛋白酸钠 / 乳清分离蛋白 / 乳清浓缩蛋白 / 蛋白-铁复合物 / 乳浊液的氧化}

Résumé - Complexes protéines laitières-fer : inhibition de l'oxydation des lipides dans une émulsion. La fortification en fer des aliments est utilisée couramment pour apporter aux consommateurs les quantités nécessaires en fer. Cependant, beaucoup de problèmes technologiques surviennent quand les produits alimentaires sont fortifiés avec des minéraux, principalement en raison de nombreuses réactions des minéraux avec les autres composants des aliments, par exemple

*Corresponding author (通讯作者): H.Singh@massey.ac.nz 
l'oxydation de la matière grasse. Dans la présente étude, la liaison du fer (sulfate de fer) à des produits protéiques laitiers courants, caséinate de sodium, isolat de protéines de lactosérum et concentré de protéines laitières, pour former des complexes protéines-fer a été caractérisée par la quantité de fer lié et la turbidité en fonction de la concentration en fer. Dans une émulsion contenant de l'acide linoléique, l'activité oxydante de ces complexes protéines-fer a été comparée avec l'activité oxydante du fer à l'état libre. Les affinités du caséinate et du concentré de protéines laitières pour lier le fer étaient plus élevées que celle de l'isolat de protéines de lactosérum. Ces différences ont été attribuées à la présence dans les molécules de caséine d'amas de résidus phosphosérine qui sont connus pour lier fortement les cations divalents. Les essais d'oxydation des lipides ont montré que la capacité du fer à catalyser l'oxydation des lipides était significativement réduite quand le fer était lié aux protéines par rapport à celle obtenue quand le fer était à l'état libre. Ceci suggère que les complexes protéines laitières-fer pourraient devenir une nouvelle voie d'incorporation de fer dans les produits alimentaires.

caséinate de sodium / isolat de protéines de lactosérum / concentré de protéines laitières / complexe protéine-fer / oxydation dans les émulsions

\section{INTRODUCTION}

Fortification of foods is a common vehicle for delivering essential minerals, such as iron, to the consumer in required concentrations, thus helping to prevent iron deficiency in human beings, which is a major nutritional problem worldwide [8]. As a result, a number of food products have been fortified with a variety of iron sources [3]. However, many technological problems occur when food products are fortified with iron, due mainly to the iron reacting with other components in the food system. These include variable bioavailability, organoleptic defects, the formation of sediment and lipid oxidation. Lipid oxidation is known to be catalysed by transition metals, notably iron. Therefore, to fortify food products with iron, researchers have attempted either to complex the added iron with macromolecules or to use a chelated form of iron to minimize its impact on lipid oxidation [6].

Hekmat and McMahon [7] found that oxidation of fat occurred in milk fortified with ferrous sulphate and ferrous ammonium sulphate. This oxidation was reduced by using a chelated form of iron for milk fortification. They suggested that, if the iron was bound and unable to move between the ferrous and ferric states (so that it could not catalyse oxidation), the oxidative deterioration could be prevented.
The formation of casein-iron complexes induces the oxidation of iron from the ferrous state to the ferric state [11]. The characteristics of different iron complexes as donors to caseins were investigated by Hegenauer et al. [6]. It was found that lipid peroxidation in iron-supplemented milk was significantly lower when the milk was supplemented with chelated forms of iron, such as ferric ethylenediaminetetraacetate, ferric nitrilotriacetate (NTA), ferric fructose, ferric lactobionate and ferric polyphosphate, than when it was supplemented with ferrous sulphate. Exchange of iron between the ferric NTA chelate and the phosphoserine residues of casein meant that the iron was bound more strongly to casein than to the original chelate. This served to remove iron from the environment of the oxidizable milk fat and to lower its tendency to oxidize milk fat. Thus, such iron complexes may be suitable iron donors for the fortification of milk in order to preserve its organoleptic stability $[2,6]$. Recently, the binding of iron (ferrous sulphate) to commercial milk protein products, sodium caseinate and whey protein isolate (WPI), as a function of $\mathrm{pH}$ and iron concentration was examined in our laboratory [17]. It was found that caseinate $(n=14)$ had more side chains than WPI $(n=8)$ for binding iron, and that the affinity of caseinate to bind iron was greater than that of WPI. However, few studies on the 
application of milk protein-iron complexes in an emulsion system containing oxidizable lipid have been reported.

Therefore, in this study, the ability of milk protein-iron complexes to influence the rate of lipid oxidation in a model linoleic acid emulsion system was investigated. The objectives of this work were to examine the extent of the oxidation of linoleic acid emulsions in the presence of protein-iron complexes and to compare the pro-oxidant effect of the bound iron with that of the iron in its free form.

\section{MATERIALS AND METHODS}

\subsection{Material}

Ferrous sulphate heptahydrate $\left(\mathrm{FeSO}_{4} \cdot 7 \mathrm{H}_{2} \mathrm{O}\right)$, certified iron standard solutions (Spectrosol) and HEPES buffer $(\mathrm{N}-2$ hydroxyethylpiperazine- $N$ '-2-ethanesulphonic acid) were obtained from BDH Chemicals, Poole, England. Water was purified using a Milli-Q system (Millipore Corp., Bedford, MA, USA). Sodium caseinate (ALANATE 180), WPI (895) and milk protein concentrate (MPC 4850) were obtained from Fonterra Co-operative Group Ltd., Palmerston North, New Zealand. The composition of these powders is shown in Table I. The original protein solutions contained very small amounts of iron $\left(\sim 0.1 \mathrm{mmol} \cdot \mathrm{L}^{-1}\right)$. The range of iron concentrations used in the binding experiments was from 0 to $10 \mathrm{mmol} \cdot \mathrm{L}^{-1}$, i.e. far in excess of the iron concentration in the original protein solutions.

\subsection{Preparation of HEPES buffer and iron solutions}

HEPES buffer $\left(50 \mathrm{mmol} \cdot \mathrm{L}^{-1}, \mathrm{pH} 6.6\right)$ with an ionic strength of $0.1 \mathrm{~mol} \cdot \mathrm{L}^{-1}$ was prepared by dissolving $11.92 \mathrm{~g}$ of HEPES buffer, $5 \mathrm{~mL}$ of $1 \mathrm{~mol} \cdot \mathrm{L}^{-1} \mathrm{NaOH}$ and $95 \mathrm{~mL}$ of $1 \mathrm{~mol} \cdot \mathrm{L}^{-1} \mathrm{NaCl}$ in $\sim 800 \mathrm{~mL}$ of Milli-Q water. The $\mathrm{pH}$ was adjusted to 6.6 , and the solution was made up to $1 \mathrm{~L}$.
Table I. Composition of sodium caseinate, MPC and WPI powders*.

\begin{tabular}{|c|c|c|c|}
\hline \multirow[t]{2}{*}{ Component } & \multicolumn{3}{|c|}{$\begin{array}{c}\text { Concentration } \\
\left(\mathrm{g} \cdot 100 \mathrm{~g}^{-1} \text { powder }\right)\end{array}$} \\
\hline & $\begin{array}{l}\text { Sodium } \\
\text { caseinate }\end{array}$ & MPC & WPI \\
\hline Protein & 93.1 & 84.5 & 93.9 \\
\hline Fat & 0.6 & 1.5 & 0.3 \\
\hline Moisture & 4.8 & 4.8 & 4.6 \\
\hline Ash & $\sim 1.5$ & 7.4 & 1.9 \\
\hline Lactose & 0.5 & 3.0 & $<0.5$ \\
\hline
\end{tabular}

* Data from Fonterra Co-operative Group Ltd., Palmerston North, New Zealand.

A $50 \mathrm{mmol} \cdot \mathrm{L}^{-1}$ solution of ferrous sulphate in this HEPES buffer was prepared. HEPES buffer was used in this study because it is highly soluble in water and forms only weak complexes with metal ions (e.g. magnesium, calcium and manganese) [15].

\subsection{Binding of iron to proteins}

Mixtures of protein (sodium caseinate, WPI and MPC) and iron were prepared by mixing the protein product with the iron solution. These mixtures had a final protein concentration of $10 \mathrm{mg} \cdot \mathrm{L}^{-1}$ and a final iron concentration ranging from 0 to $10 \mathrm{mmol} \cdot \mathrm{L}^{-1}$. The $\mathrm{pH}$ of the mixture was adjusted to 6.6 using $0.5 \mathrm{~mol} \cdot \mathrm{L}^{-1} \mathrm{NaOH}$. The protein-iron mixture was stirred and then left at room temperature $\left(\sim 20^{\circ} \mathrm{C}\right)$ for $2 \mathrm{~h}$. The mixture was then centrifuged at $10800 \times g$ at $20^{\circ} \mathrm{C}$ for $20 \mathrm{~min}$. The supernatant contained "soluble" protein, "soluble" protein-iron complexes and soluble "free" iron. Measurements of iron binding were carried out on the soluble fraction by analysing the supernatant. The supernatant was carefully decanted and analysed for concentrations of iron.

To separate the soluble "free" iron from the iron bound to soluble protein, a portion of the supernatant was passed through an Amicon stirred ultrafiltration (UF) 
cell (Model 8050, Amicon Division, W.R. Grace and Co., Danvers, MA, USA), containing a Diafilo UF membrane YM 10 (molecular weight cut-off 10000 ), at a pressure of $300 \mathrm{kPa}$. The UF permeate, which contained the soluble "free" iron, was analysed for its iron concentration.

\subsection{Determination of iron content}

The iron content of the samples was determined by atomic absorption spectroscopy (GBC 933 AA, GBC Scientific Equipment Pty Ltd., Dandenong, Victoria, Australia). The acetylene-air flame was optimized prior to measurement of the samples.

Iron standards were made up either in purified water or, for one set of experiments, in a $0.001 \mathrm{mg} \cdot \mathrm{L}^{-1}$ of sodium caseinate solution. The standards prepared in sodium caseinate solution gave the same readings as the standards prepared in water, indicating that protein solutions at a concentration of $0.001 \mathrm{mg} \cdot \mathrm{L}^{-1} \mathrm{did}$ not interfere with the atomic absorption spectroscopy measurements. Therefore, iron standards made up in purified water were used to obtain the standard curve for measurement of the protein-iron samples.

\subsection{Turbidity measurements}

The turbidity of each protein-iron mixture (before centrifugation) was measured using a UV-visible spectrophotometer (Pharmacia LKB Ultrospec II). Approximately $3 \mathrm{~mL}$ of each sample were placed in a $4 \mathrm{~mL}$ plastic cuvette. The absorbance of each sample was measured at $650 \mathrm{~nm}$, against $\sim 3 \mathrm{~mL}$ of $50 \mathrm{mmol} \cdot \mathrm{L}^{-1}$ HEPES buffer as the reference standard.

\subsection{Oxidation of linoleic acid in emulsion}

A linoleic acid emulsion consisting of linoleic acid (0.2804 g), Tween 20 (0.2804 g) and $50 \mathrm{~mL}$ of phosphate buffer $\left(0.2 \mathrm{~mol} \cdot \mathrm{L}^{-1}\right.$,
$\mathrm{pH}$ 7.4) was prepared at room temperature using a laboratory high-speed mixer (10 $000 \mathrm{rev} \cdot \mathrm{min}^{-1}$ for $2 \mathrm{~min}$ ) (Diax 600, Heidolph, Germany). The average droplet size of the emulsion $\left(d_{32}\right)$ was $\sim 8.2 \mu \mathrm{m}$, which was determined by a Malvern MasterSizer MSE (Malvern Instruments Ltd., Malvern, Worcestershire, UK), as described previously [20].

Different samples containing protein and/ or iron were prepared as follows. Protein solutions $\left(10 \mathrm{mg} \cdot \mathrm{L}^{-1}\right)$ were prepared by dissolving the protein powders in HEPES buffer. Solutions containing free iron were prepared by mixing $25 \mathrm{~mL}$ of $50 \mathrm{mmol} \cdot \mathrm{L}^{-1}$ HEPES buffer and iron from the stock solution. HEPES buffer was then added to give a final volume of $50 \mathrm{~mL}$ and a final iron concentration of $1 \mathrm{mmol} \cdot \mathrm{L}^{-1}$. Protein-iron mixtures containing a final iron concentration of $1 \mathrm{mmol} \cdot \mathrm{L}^{-1}$ were prepared by mixing $25 \mathrm{~mL}$ of $20 \mathrm{mg} \cdot \mathrm{L}^{-1}$ protein solution and iron from the stock solution. HEPES buffer was then added to give a final volume of $50 \mathrm{~mL}$. All these sample solutions were then stirred for $2 \mathrm{~h}$ at ambient temperature.

After stirring, $1 \mathrm{~mL}$ of each of these sample solutions was added to $5 \mathrm{~mL}$ of linoleic acid emulsion. These mixtures were then held, without stirring, at $30{ }^{\circ} \mathrm{C}$ for different times up to $72 \mathrm{~h}$. At the end of the designated time period, samples were analysed for oxidation of linoleic acid. All samples were held in the dark to prevent any oxidation due to light. Control samples of linoleic acid emulsion, held at $4{ }^{\circ} \mathrm{C}$ and at $30^{\circ} \mathrm{C}$ in the dark, were also included in the experiment.

\subsection{Thiobarbituric acid test}

The extent of oxidation of linoleic acid was measured by the thiobarbituric acid (TBA) method according to Hegenauer et al. [6]. The TBA reagent was prepared immediately before use by mixing equal volumes of freshly prepared $0.025 \mathrm{~mol} \cdot \mathrm{L}^{-1}$ TBA (brought into solution by neutralizing 
with $\mathrm{NaOH}$ ) and $2 \mathrm{~mol} \cdot \mathrm{L}^{-1} \quad \mathrm{H}_{3} \mathrm{PO}_{4} /$ $2 \mathrm{~mol} \cdot \mathrm{L}^{-1}$ citric acid. The combination of citric acid and phosphoric acid was used as both an acidulant and a metal chelator.

At the end of the holding period, $5 \mathrm{~mL}$ of the sample were pipetted into a $50 \mathrm{~mL}$ centrifuge tube containing $2.5 \mathrm{~mL}$ of the TBA reagent. The contents of the tube were mixed and the tube was placed without delay in a boiling water bath for exactly $10 \mathrm{~min}$. After heating, the mixture was cooled in ice and then $5 \mathrm{~mL}$ of cyclohexanone and $1 \mathrm{~mL}$ of $4 \mathrm{~mol} \cdot \mathrm{L}^{-1}$ ammonium sulphate were added. The tube was shaken for $2 \mathrm{~min}$ and centrifuged at $6000 \times g$ for $5 \mathrm{~min}$ at room temperature. The orange-red cyclohexanone supernatant was decanted and its absorbance at $532 \mathrm{~nm}$ was measured spectrophotometrically (Shimadzu, UV-160A UVvisible spectrophotometer).

As malondialdehyde (MDA) is unstable, standards are usually prepared by acid hydrolysis of 1,1,3,3-tetraethoxypropane (TEP) [9]. TEP (73.2 mg) was accurately weighed into a screw-capped test tube, dissolved in $10 \mathrm{~mL}$ of $0.1 \mathrm{~mol} \cdot \mathrm{L}^{-1} \mathrm{HCl}$, immersed into a boiling water bath for 5 min and quickly cooled in tap water. A stock solution of MDA $\left(239 \mu \mathrm{g} \cdot \mathrm{mL}^{-1}\right)$ was prepared by transferring the hydrolysed TEP solution into a $100 \mathrm{~mL}$ volumetric flask and diluting to volume with water. The stock solution was diluted further with water to give MDA solutions of various concentrations (from 0 to $2.2 \mu \mathrm{g} \cdot \mathrm{mL}^{-1}$ ). A $5 \mathrm{~mL}$ aliquot of each of these solutions was reacted with TBA (as described above) and the absorbance of the red-coloured complex was measured at $532 \mathrm{~nm}$. These results showed a linear relationship between the absorbance and the concentration of the MDA standards.

\subsection{Statistical analysis}

The samples were prepared in duplicate. The results were analysed statistically using the Minitab 12 for Windows package.

\section{RESULTS}

\subsection{Characterization of protein-iron complexes}

The amounts of iron binding to sodium caseinate, WPI and MPC, calculated from the amount of iron in the UF permeate, as a function of the concentration of iron added to the protein solutions are shown in Figure 1. At added iron concentrations of $<4 \mathrm{mmol} \cdot \mathrm{L}^{-1}$, more than $96 \%$ of the total added iron was bound to protein in the sodium caseinate-iron and MPC-iron mixtures and about $90 \%$ was bound to protein in the WPI-iron mixtures. These results indicate that most of the added iron in the mixtures formed protein-iron complexes. There was a decrease in iron binding at added iron concentrations above $4 \mathrm{mmol} \cdot \mathrm{L}^{-1}$, probably because the iron and the proteins precipitated at different rates in the protein-iron mixtures at added iron concentrations above $4 \mathrm{mmol} \cdot \mathrm{L}^{-1}$.

More iron bound to sodium caseinate and MPC than to WPI (Fig. 1). This was expected because caseins are known to have a stronger binding capacity for metal cations than whey proteins, mainly because of the presence of clusters of phosphoserine residues. The more compact structure of the whey protein in WPI, compared with the more flexible, open structure of sodium caseinate, could also account for the differences in their ability to bind added iron [5, 17].

MPC and sodium caseinate bound similar amounts of iron, even though the casein content in MPC is lower than that in caseinate (Fig. 1). This could have been due to the structure of the caseins in MPC, which is similar to that found in milk, i.e. composed of micelles and colloidal calcium phosphate. In sodium caseinate, the casein fractions are present as monomers and small complexes and iron binds mainly to the phosphoserine residues on the casein molecules. In contrast, in MPC, the phosphoserine residues are not available because they interact with calcium 


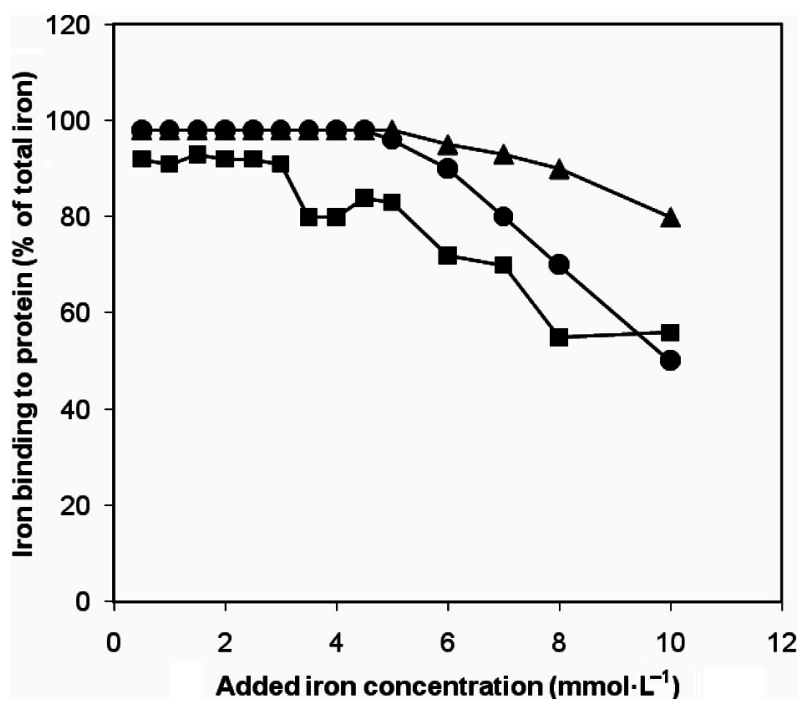

Figure 1. Amount of iron ( $\%$ of total added iron) binding to protein in sodium caseinate-iron $(\bullet)$, WPI-iron (ם) and MPC-iron $(\boldsymbol{\Delta})$ mixtures $\left(10 \mathrm{mg} \cdot \mathrm{L}^{-1}\right.$ protein) in $50 \mathrm{mmol} \cdot \mathrm{L}^{-1} \mathrm{HEPES}$ buffer at $\mathrm{pH}$ 6.6. Each point is the average of determinations on two separate samples.

phosphate to form colloidal calcium phosphate [13]. Therefore, it is likely that MPC bound the greatest amount of iron because of the presence of the casein micelles, and the whey protein fractions also have the ability to bind iron. A study by Gaucheron et al. [5] on the addition of $\mathrm{FeCl}_{2}$ and $\mathrm{FeCl}_{3}$ to skim milk found that more than $89 \%$ of the iron was bound to the colloidal phase (casein micelles) with a small amount of the iron found in the aqueous phase.

Addition of iron at relatively high concentrations may lead to a decrease in the solubility of protein [17]. The low solubility of protein-iron complex may influence the functional properties including antioxidative activity in the liquid systems. The solubility of the protein-iron complexes was examined at different iron concentrations (from 1 to $5 \mathrm{mmol} \cdot \mathrm{L}^{-1}$ ) using turbidity measurements at a wavelength of $650 \mathrm{~nm}$ (Fig. 2). The turbidity increased as the amount of added iron increased in all three protein-iron mixtures. There was only a slight increase in the turbidity of the sodium caseinate-iron and WPI-iron mixtures at added iron concentrations below $4 \mathrm{mmol} \cdot \mathrm{L}^{-1}$. At added iron concentrations $>4 \mathrm{mmol} \cdot \mathrm{L}^{-1}$, the turbidity of the sodium caseinate-iron mixtures increased abruptly and was greater than that of the WPI-iron mixtures. The turbidity values of the MPC-iron mixtures were much greater than those of the sodium caseinateiron and WPI-iron mixtures, indicating that casein micelles were involved in the protein-iron interactions.

The natures of the binding of iron to caseins in MPC and in sodium caseinate are likely to be different because of the different states of the casein molecules in the milk protein products. Iron is probably incorporated into the colloidal calcium phosphate, possibly displacing calcium from the phosphoserine residues and from the inorganic phosphate, forming iron phosphate. Thus, the iron in MPC is associated with both the caseins and the colloidal calcium phosphate. 


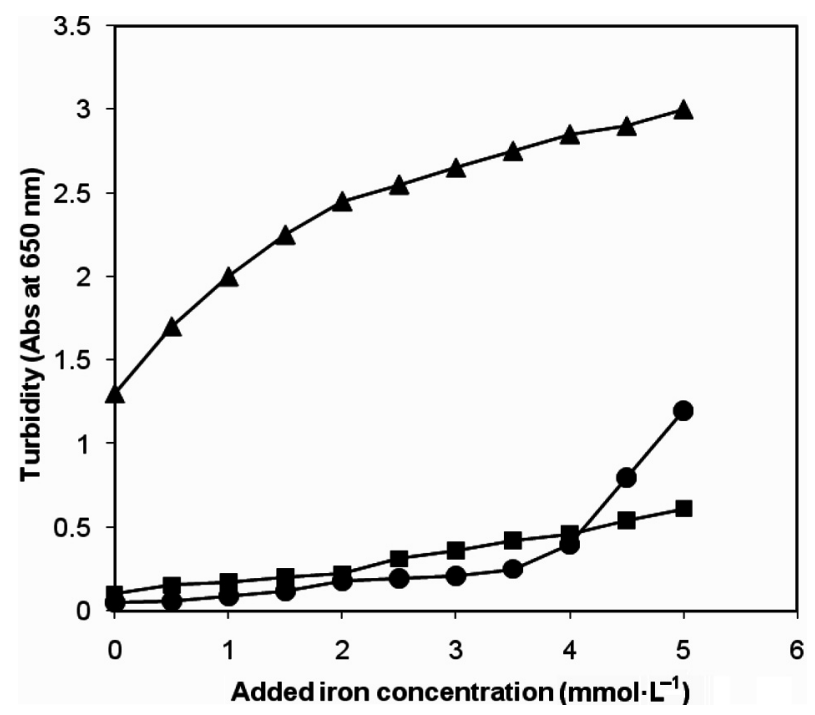

Figure 2. Turbidity (absorbance at $650 \mathrm{~nm}$ ) of sodium caseinate-iron $(\bullet)$, WPI-iron $(\mathbf{\square})$ and MPCiron $(\Delta)$ mixtures $\left(10 \mathrm{mg} \cdot \mathrm{L}^{-1}\right.$ protein) in $50 \mathrm{mmol} \cdot \mathrm{L}^{-1}$ HEPES buffer at $\mathrm{pH}$ 6.6. Each point is the average of determinations on two separate samples.

\subsection{Effect of protein binding on iron-catalysed lipid oxidation}

The extent of lipid oxidation in a Tween20-stabilized linoleic acid emulsion containing iron was determined using the TBA test. Samples were held at $30^{\circ} \mathrm{C}$ in the dark for up to $72 \mathrm{~h}$. The oxidation activity of the iron bound to the protein-iron complexes $\left(1 \mathrm{mmol} \cdot \mathrm{L}^{-1}\right.$ iron and $10 \mathrm{mg} \cdot \mathrm{L}^{-1}$ protein, respectively) was compared with that of the iron in its free state (unbound) at the same concentration. The iron concentration in the samples was $1 \mathrm{mmol} \cdot \mathrm{L}^{-1}$ because, at this concentration, over $90 \%$ of the added iron was bound to the milk proteins and there was very little protein aggregation (Figs. 1 and 2).

Linoleic acid emulsion was used as a control. The absorbance readings of the TBA reaction products from the oxidation of linoleic acid increased slightly over the incubation period up to $72 \mathrm{~h}$ (Fig. 3).
This indicated that the linoleic acid was not oxidized at the start of the experiment and oxidized only slowly in the emulsion under the experimental conditions.

The absorbance readings of the TBA reaction products from the oxidation of linoleic acid catalysed by free iron $\left(1 \mathrm{mmol} \cdot \mathrm{L}^{-1}\right)$ increased markedly with storage time (Figs. 3-5), indicating that the oxidation of linoleic acid in the emulsion was faster when it was catalysed by free iron. However, when protein-iron complexes were added to the emulsion, the absorbance readings were much lower than of the linoleic acid emulsion containing free iron at the same storage time. For example, after $72 \mathrm{~h}$, the absorbance readings for the oxidation of linoleic acid catalysed by sodium caseinate-iron, WPI-iron and MPC-iron complexes were, respectively, $\sim 6,1.5$ and 4 times lower than that for the oxidation of linoleic acid catalysed by free iron. The absorbance readings for the emulsions containing sodium 


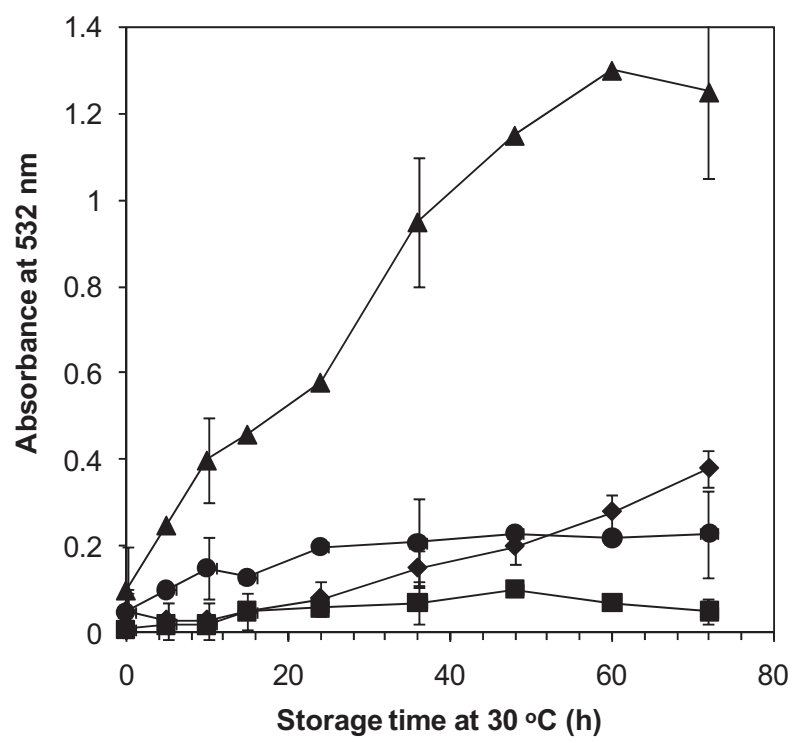

Figure 3. Absorbance readings of TBA reaction products from the oxidation of linoleic acid in Tween-20-stabilized emulsions. Samples were held at $30^{\circ} \mathrm{C}$, in the dark, for up to $72 \mathrm{~h}$. Data are the average of two trials: ( $\diamond$ ) linoleic acid emulsion (control); (■) linoleic acid emulsion with sodium caseinate solution $\left(10 \mathrm{mg} \cdot \mathrm{L}^{-1}\right.$ protein); ( $\left.\boldsymbol{\Delta}\right)$ linoleic acid emulsion with $1 \mathrm{mmol} \cdot \mathrm{L}^{-1}$ free ferrous ions; and (๑) linoleic acid emulsion with sodium caseinate-iron complex. Each point is the average of determinations on two separate samples. Bars indicate standard errors.

caseinate-iron and MPC-iron complexes were even lower than that of the control emulsion containing no iron after $72 \mathrm{~h}$ of storage. These results indicate that the ability of iron to catalyse lipid oxidation was reduced significantly when the iron was bound (to protein) than when it was in its free form. Furthermore, the extent to which the different protein-iron complexes reduced the rate of oxidation varied; the sodium caseinate-iron complex and the MPC-iron complex seemed to show lower oxidation activity than the WPI-iron complex.

For comparison, experiments on linoleic acid emulsions containing only $10 \mathrm{mg} \cdot \mathrm{L}^{-1}$ sodium caseinate, WPI and MPC were carried out. The rates of oxidation of the linoleic acid emulsion in the presence of $10 \mathrm{mg} \cdot \mathrm{L}^{-1}$ caseinate, WPI and MPC were slower than that of the linoleic acid emulsion containing no protein (Figs. 3-5). Each milk protein appeared to act as an antioxidant, with the effect being greater for sodium caseinate and MPC than for WPI. Indeed, for the linoleic acid emulsion containing sodium caseinate, the absorbance readings showed little increase over the incubation period (from 0.02 to 0.06 ) (Fig. 3), suggesting that sodium caseinate effectively prevented the oxidation of linoleic acid.

\section{DISCUSSION}

Transition metals that possess two or more valence states with a suitable oxidation-reduction potential between them (e.g. copper and iron) are capable of undergoing reversible one-electron reactions. These metal ions are considered to act as 


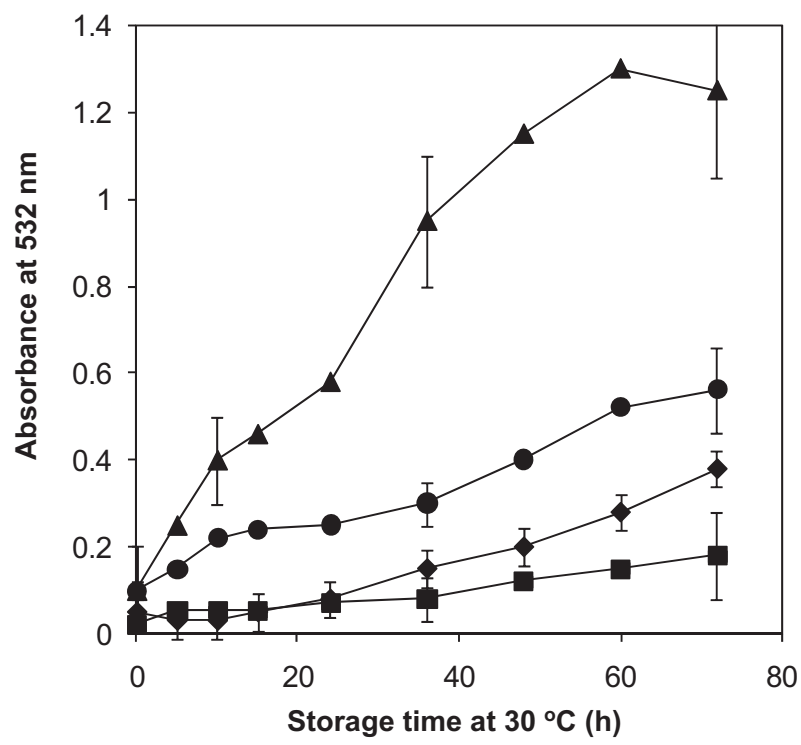

Figure 4. Absorbance readings of TBA reaction products from the oxidation of linoleic acid in Tween-20-stabilized emulsions. Samples were held at $30^{\circ} \mathrm{C}$, in the dark, for up to $72 \mathrm{~h}$. Data are

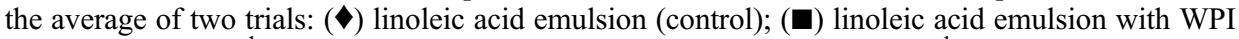
solution $\left(10 \mathrm{mg} \cdot \mathrm{L}^{-1}\right.$ protein); ( $\left.\boldsymbol{\Delta}\right)$ linoleic acid emulsion with $1 \mathrm{mmol} \cdot \mathrm{L}^{-1}$ free ferrous ions; and (•) linoleic acid emulsion with WPI-iron complex. Each point is the average of determinations on two separate samples. Bars indicate standard errors.

pro-oxidants, primarily by catalysing the decomposition of hydroperoxides ( $\mathrm{ROOH})$, as shown in the following equations [10]:

$$
\begin{array}{r}
\mathrm{M}^{n+}+\mathrm{ROOH} \rightarrow \mathrm{M}^{(n+1)+}+\mathrm{OH}^{-}+\mathrm{RO}^{\bullet}, \\
\mathrm{M}^{(n+1)+}+\mathrm{ROOH} \rightarrow \mathrm{M}^{n+}+\mathrm{H}^{+}+\mathrm{ROO} .
\end{array}
$$

Thus, small quantities of an appropriate metal ion can generate large numbers of chain reactions by cycling between the oxidized and reduced forms. Whereas these ions are effective reducers of hydroperoxides in their reduced states (equation (1)), they are less efficient oxidizers in their higher oxidation states (equation (2)) [10, 14].
Furthermore, these metal ions may act as pro-oxidants by generating the active oxygen species, singlet oxygen, which can react directly with unsaturated fatty acids to produce hydroperoxides [16].

The marked effect on the rate of oxidation caused by the presence of free (unbound) iron is shown in Figures 3-5. The rate of oxidation of linoleic acid in the presence of free ferrous ions was found to be markedly higher than that of the control (linoleic acid with no additives). It has been suggested that adding ferrous iron to an unsaturated lipid would produce active oxygen species, which would then initiate the first step of the chain reaction of lipid peroxidation [22].

The present study showed that the rate of oxidation of linoleic acid was slower when the iron was complexed to milk proteins than when the iron was present in its free 


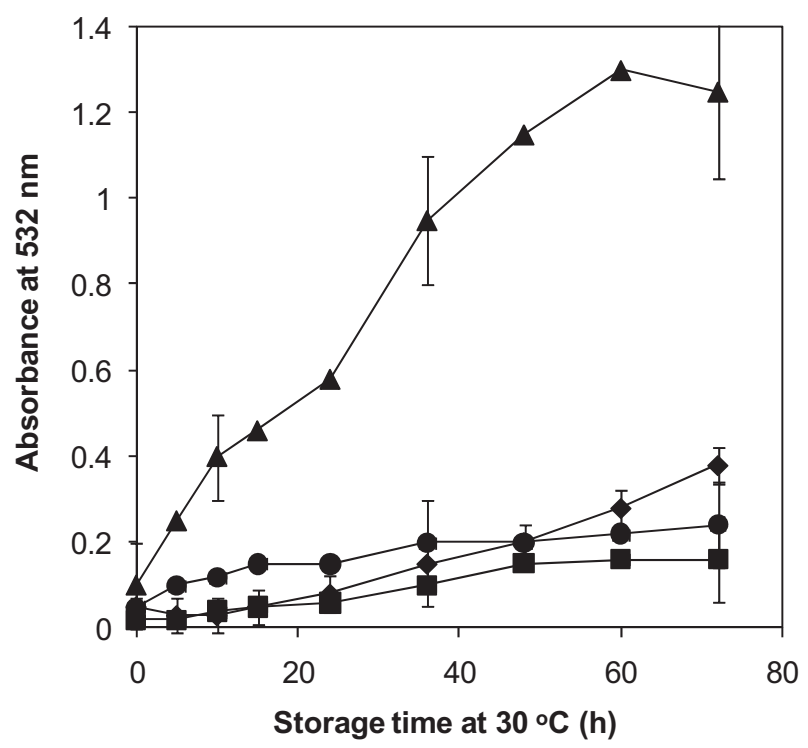

Figure 5. Absorbance readings of TBA reaction products from the oxidation of linoleic acid in Tween-20-stabilized emulsions. Samples were held at $30^{\circ} \mathrm{C}$, in the dark, for up to $72 \mathrm{~h}$. Data are the average of two trials: ( ) linoleic acid emulsion (control); ( $\mathbf{\square})$ linoleic acid emulsion with MPC solution $\left(10 \mathrm{mg} \cdot \mathrm{L}^{-1}\right.$ protein); $(\boldsymbol{\Delta})$ linoleic acid emulsion with $1 \mathrm{mmol} \cdot \mathrm{L}^{-1}$ free ferrous ions; and (•) linoleic acid emulsion with MPC-iron complex. Each point is the average of determinations on two separate samples. Bars indicate standard errors.

(unbound) form, regardless of the type of milk protein (i.e. sodium caseinate, WPI or MPC) that bound the iron. Hegenauer et al. [6] showed that chelated forms of iron were more preferable as supplements for milk than simple inorganic salts (ferrous sulphate or ferrous chloride). The unbound ferrous ion could participate in the cyclic oxidationreduction reactions, therefore amplifying its potential for catalysing lipid oxidation. In contrast, chelated forms of iron, such as ferric NTA, removed the metal from the environment of the lipid fraction, which decreased the rate of oxidation. Therefore, at the same concentration, iron presented as ferric chelate (ferric lactobionate and ferric NTA) caused less oxidation than free ferrous iron.

In the current investigation, when milk proteins were present in the sample, the oxidation of linoleic acid was suppressed when compared with the control (linoleic acid with no additives). Of the three milk proteins used, WPI was less effective than casein proteins (i.e. sodium caseinate and MPC) at suppressing oxidation, which is in agreement with some published studies. Taylor and Richardson [18] found that the caseins had much greater antioxidant activity than the whey proteins. Reviews by Richardson and Korycka-Dahl [16] and O'Connor and O'Brien [14] also stated that casein proteins have antioxidative properties that appear to be related to their hydrophobic nature and the orientation of potential antioxidant side chains of constituent amino acids at the lipid interface $[1,4,21]$.

Caseins may also act as antioxidants because they have the ability to bind prooxidant metals to their phosphoserine residues $[6,11]$, which inhibits the catalytic 
effect of the metals [1]. The present study showed that iron added as ferrous sulphate was bound completely to the casein molecules in sodium caseinate at added iron concentrations up to $4 \mathrm{mmol} \cdot \mathrm{L}^{-1}$ (Fig. 1). The soluble caseins and the casein micelles in MPC have also been shown to have the ability to bind significant amounts of iron. Therefore, when the added iron was bound completely to casein molecules, the catalytic effect of iron was prevented, which led to much lower rates of lipid oxidation.

Whey proteins were also demonstrated to prevent oxidation, but to be less effective as antioxidants than caseins (Fig. 4). The antioxidative properties of whey protein are probably a result of its free radical scavenging activity due to its free sulphydryl groups $[12,14,19]$. The lower effectiveness of WPI, compared with caseinate and MPC, as an antioxidant is possibly due to the lower iron-binding ability of the whey proteins. The present study found that, for sodium caseinate and MPC, all the iron was completely bound at relatively low concentrations of added iron. In other words, no free iron was present. However, for WPI, a small amount of free iron was always present, even at low concentrations of added iron (Fig. 1).

\section{CONCLUSION}

At a low concentration of added iron $\left(<4 \mathrm{mmol} \cdot \mathrm{L}^{-1}\right)$, most of the iron could bind to milk protein to form protein-iron complexes. The binding of iron depended on the type of protein product. Sodium caseinate and MPC had greater iron binding than WPI. The protein-iron complexes had slightly lower solubility than the protein solutions. For the same iron concentration, the ability of iron to catalyse lipid oxidation was reduced significantly when these protein-iron complexes were added to a linoleic acid emulsion. This suggests that the catalytic oxidation activity of iron in a food can be controlled by binding the iron to protein to form a complex. Milk protein-iron complexes could be a novel way of incorporating iron into food products with high bioavailability, good flavour and no solubility problems.

Acknowledgement: The authors wish to acknowledge the NZAID Programme and Fonterra Co-operative Group Ltd., New Zealand, for funding this project.

\section{REFERENCES}

[1] Allen J.C., Wrieden W.L., Influence of milk-proteins on lipid oxidation in aqueous emulsion. 1. Casein, whey-protein and alphalactalbumin, J. Dairy Res. 49 (1982) 239-248.

[2] Carmichael D., Christopher J., Hegenauer J., Saltman P., Effect of milk and casein on absorption of supplemental iron in mouse and chick, Am. J. Clin. Nutr. 28 (1975) 487-493.

[3] Douglas F.W., Rainey N.H., Wong N.P., Edmondson L.F., Lacroix D.E., Color, flavor, and iron bioavailability in iron-fortified chocolate milk, J. Dairy Sci. 64 (1981) 1785-1793.

[4] Eriksson C.E., Lipid oxidation catalysts and inhibitors in raw-materials and processed foods, Food Chem. 9 (1982) 1-2.

[5] Gaucheron F., Le Graet Y., Raulot K., Piot M., Physicochemical characterisation of ironsupplemented skim milk, Int. Dairy J. 7 (1997) 141-148.

[6] Hegenauer J., Saltman P., Ludwig D., Ripley L., Ley A., Iron-supplemented cow milk identification and spectral properties of iron bound to casein micelles, J. Agric. Food Chem. 27 (1979) 1294-1301.

[7] Hekmat S., McMahon D.J., Distribution of iron between caseins and whey proteins in acidified milk, Lebensm. Wiss. Technol. 31 (1998) 632-638.

[8] Hurrell R.F., Cook J.D., Strategies for iron fortification of foods, Trends Food Sci. Technol. 9 (1990) 56-61.

[9] Inoue T., Ando K., Kikugawa K., Specific determination of malonaldehyde by N-methyl2-phenylindone or thiobarbituric acid, J. Am. Oil Chem. Soc. 75 (1998) 597-600. 
[10] Labuza T.P., Kinetics of lipid oxidation in foods, CRC Crit. Rev. Food Technol. 2 (1971) 355-404.

[11] Manson W., Cannon J., Reaction of $\alpha$-s1 and $\beta$-casein with ferrous ions in presence of oxygen, J. Dairy Res. 45 (1978) 59-67.

[12] McClements D.J., Decker E.A., Lipid oxidation in oil-in-water emulsions: impact of molecular environment on chemical reactions in heterogeneous food systems, J. Food Sci. 65 (2000) 1270-1282.

[13] Mulvihill D.M., Production, functional properties and utilization of milk protein products, in: Fox P.F. (Ed.), Advanced Dairy Chemistry - 1. Proteins, Elsevier Applied Science Publishers, London, UK, 1992, pp. 369-405.

[14] O’Connor T.P., O’Brien N.M., Lipid oxidation, in: Fox P.F. (Ed.), Advanced Dairy Chemistry, Vol. 2, Chapman and Hall, London, UK, 1995, pp. 309-347.

[15] Perrin D., Dempsey B., Buffers for $\mathrm{pH}$ and Metal Ion Control, Chapman and Hall, London, UK, 1974.

[16] Richardson T., Korycka-Dahl M., Lipid oxidation, in: Fox P.F. (Ed.), Developments in Dairy Chemistry, Vol. 1, Elsevier Applied
Science Publishers, London, UK, 1983, pp. 241-363.

[17] Sugiarto M., Ye A., Singh H., Characterization of binding of iron to sodium caseinate and whey protein isolate, Food Chem. 114 (2009) 1007-1013.

[18] Taylor M.J., Richardson T., Antioxidant activity of skim milk: effect of heat and resultant sulfhydryl groups, J. Dairy Sci. 63 (1980) 1783-1795.

[19] Tong L.M., Sasaki S., McClements D.J., Decker E.A., Mechanisms of the antioxidant activity of a high molecular weight fraction of whey, J. Agric. Food Chem. 48 (2000) 1473-1478.

[20] Ye A., Interfacial composition and stability of emulsions made with mixtures of sodium caseinate and whey protein concentrate, Food Chem. 110 (2008) 946-952.

[21] Yee J.J., Shipe W.F., Effects of sulfhydryl compounds on lipid oxidations catalyzed by copper and heme, J. Dairy Sci. 65 (1982) 1414-1420.

[22] Yen G.C., Chen H.Y., Lee C.E., Measurement of antioxidative activity in metal ioninduced lipid peroxidation systems, J. Sci. Food Agric. 79 (1999) 1213-1217. 